\title{
Human Trafficking in Woman and Children Perspective; Protocol to Prevent, Suppress and Punish in Persons
}

\author{
I Wayan Putu Sucana Aryana ${ }^{\Omega}$ \\ Faculty of Law, Universitas Ngurah Rai \\ ^email correspondence: sucanaarvana67@gmail.com
}

\begin{abstract}
Trafficking in persons is a cross-border crime which injures human dignity. The mode of trafficking in persons is to take advantage of the economic conditions of potential victims by luring them a better job. This research will discuss the profile of victims of trafficking in persons, gender analysis in human trafficking, and international policies in victim protection that are gender equality oriented. This research is a normative juridical study examining the analysis of international legal instruments, laws and court decisions. The research was conducted using the statute approach, legal concepts and the concept of gender. The victims of trafficking in persons are dominated by women, although it does not rule out the possibility that men can also be the victims. Women are considered as commodities that can provide benefits because they can be bought and sold to do work without requiring high education, and even provide sexual services. The perpetrators of the criminal network carry out the recruitment of potential victims by involving the householder of the potential victim, in this case the husband or father of the potential victim. This condition cannot be separated from the deep rooted patriarchal culture in the society, in which the men play a role as the decision makers in the family. Power relations play an important role in analyzing this crime of trafficking in persons. Efforts to combat trafficking in persons are carried out within the framework of a gender-equitable policy. However, the existing legal instruments have not addressed the fundamental problems of trafficking in women. Reconstruction of the legal culture of society is very important in protecting women from various forms of violence.
\end{abstract}

Keywords: Human trafficking; Gender; Women.

Date of Submission: March 09, 2021

Date of Publication: June 29, 2021

DOI: http://dx.doi.org/10.33096/substantivejustice.v4i1.124

\section{INTRODUCTION}

Trafficking in human beings in the modern world is one of the most brutal mass violations of human rights and freedoms. The social threat to trafficking in human beings as an extremely dangerous crime is to encroach on the inalienable human rights of the right to respect, liberty and personal integrity, freedom of movement and free choice of place of 
residence, and sometimes the right to life. ${ }^{1}$ Historically, human trafficking can be said slavery and also violate human rights. The human rights violations in the form of slavery are generally in the form of deprivation of freedom from someone, committed by strong economic groups to the weak economic groups. On this basis, the prevention of trafficking in persons in the perspective of human rights violations must be carried out comprehensively and integrally, which can be carried out at the level of criminal law policy by means of legislation, execution and judiciary. ${ }^{2}$ Criminal law policies in the prevention of criminal acts of trafficking in persons need to be carried out comprehensively, both in preventive and victim handling policy.

In global policy level, the commitment in protection against trafficking in persons is generally regulated in the United Nations Convention against Transnational Organized Crime. It is stated in the convention that :

Recalling its resolution 53/111 of 9 December 1998, in which it decided to establish an openended intergovernmental ad hoc committee for the purpose of elaborating a comprehensive international convention against transnational organized crime and of discussing the elaboration, as appropriate, of inter- national instruments addressing trafficking in women and children, combating the illicit manufacturing of and trafficking in firearms, their parts and components and ammunition, and illegal trafficking in and transporting of migrants, including by sea.

Referring to the United Nations Convention against Transnational Organized Crime, the countries actually understand that trafficking in persons cannot be carried out by just a person, but it is carried out by an organized criminal network. Jonathan Todres and Angela Diaz state that trafficking in persons continues to occur, even more likely to occur during the COVID-19 pandemic. They state "The impact of COVID-19 on trafficking survivors is significant. The virus has disrupted their lives and support networks while increasing financial stress, food insecurity, interpersonal violence, and grief over the loss of loved ones. In response, it is essential that we develop tailored strategies to meet the needs of individuals at risk of or exploited in human trafficking." ${ }^{3}$ The reduced or even loss of a person's income will open the door for criminal networks to recruit potential victims of trafficking in persons.

The criminal act of trafficking in persons is a criminal crime that affects men, women and children in various forms and ways that often occurs throughout Indonesia. They are exploited in a wide variety of sectors including agriculture, construction, tourism, domestic work, the entertainment industry and sex work, forestry, fishing, mining and others. People can be trafficked both across national borders and between provinces within a country. The victims of trafficking in persons can vary in terms of age, regional origin or ethnic background, and

1 Krutevych, M. (2018). Separate Aspects of Criminal Responsibility for Trafficking in Human Beings. elar.naiau.kiev.ua http://elar.naiau.kiev.ua/bitstream/123456789/6411/1/111\%D0\%97\%D0\%B1\%D1\%96\%D1\%80\%D0\%BD\%D0\%B8\%D0 \%BA $2018 \% 20 \%$ D0\%90\%D0\%BD\%D0\%B3\%D0\%BB p067-069.pdf

2 Nugroho, O. C. (2018). Tanggung Jawab Negara dalam Penanganan Tindak Pidana Perdagangan Orang. Jurnal Penelitian Hukum De Jure, 18(4), 543-560. DOI: http://dx.doi.org/10.30641/dejure.2018.V18.543-560

3 Todres, J., \& Diaz, A. (2021). COVID-19 and Human Trafficking the Amplified Impact on Vulnerable Populations. JAMA pediatrics, 175(2), 123-124. DOI: http://dx.doi.org/10.1001/iamapediatrics.2020.3610 
education. However, there is a similarity in the characteristics of the victims in the form of vulnerability and isolation efforts. Factors that contribute to vulnerability in Indonesia include poverty, unemployment, gender inequality, and loopholes for easy document falsification. ${ }^{4}$ Even so, the victims of trafficking in persons are dominated by women.

The modus operandi is mostly persuasion or lure, which is deception, and the modus operandi that has developed is to spread traps to public zones, such as bus terminals, ports, villages, suburbs and even city centers and so on. . The victims of trafficking generally come from poor or economically weak families, have low education or emotional weakness, from the suburbs and rural areas, although it is possible that there are middle and upper economic families in urban areas. This condition tends to be used by certain parties for their business interests by preying on women and children, because they are easily lured or persuaded, scared, lied to, cheated, and hired with low wages. ${ }^{5}$ Minimal supervision from the family and local environment,o and the competent authorities will make it easier for the perpetrator to recruit victims.

Trafficking of women is widely practiced in several countries in the world and there are even some countries that legalize prostitution to provide sexual services, such as Japan, Brazil, the Netherlands, Nevada and several other countries that often end in trafficking of women. Women are seen as attractive objects and have commercial value to be traded. Compared to men, sexual trafficking is generally carried out by sexually exploiting women. Not only within the country, trafficking of women is also often carried out across countries. Transnational trafficking of women in Indonesia often occurs in the border areas of the country. It is because the access to trafficking in women can be done easily in the border areas of the country, and also in the border areas between Indonesia and other countries are still underdeveloped and do not get enough attention from the government resulting in the difficuty to be reached and monitored by the government. ${ }^{6}$

There are also perpetrators of trafficking in persons who send their victims to Malaysia to become commercial sex workers. This case involved the Aceh, Batam and Malaysia networks. The initial mode of perpetrators of the criminal act of trafficking in persons was to invite and guarantee the victims, who were mostly Acehnese women, to work in Malaysia. Another case is the rife cases, in which the victims of human trafficking were sent to China. In September 2018, this case was experienced directly by a woman with the initials Er 21 years old. This woman who is from Bandung Regency told that she was a victim of human trafficking.

\footnotetext{
${ }^{4}$ International Organization fo Migration (2019). Petunjuk Teknis Pendataan dan Pelaporan Data Tindak Pidana Perdagangan Orang. Jakarta: International Organization for Migration (IOM) Indonesia, p. 15. https://indonesia.iom.int/id/node/631

5 Tumundo, E. (2018). Penyidikan Tindak Pidana Perdagangan Orang pada Tingkat Kepolisian dalam Perspektif Hak Asasi Manusia. Lex Et Societatis, 6(4), p. 84. DOI: https://doj.ora/10.35796/les.v6i4.19834

${ }^{6}$ Ria, W. Y. (2021). Perdagangan Perempuan Lintas Negara Sebagai Suatu Tindak Pidana Sebagaimana diatur Dalam Undang-Undang Nomor 21 Tahun 2007 Tentang Pemberantasan Tindak Pidana Perdagangan Orang dan CEDAW. Lex Crimen, 10(1), 30-38.
} 
She was married to a Chinese person. She really wanted to return to Indonesia because she felt pressured because of the violence she experienced, even if it was only in the form of harsh words, it did not extend to physical or sexual violence. The victim was forced to take uterine fertility drugs every day by the perpetrator, because he wanted to have Indonesian descent. He thought that it would bring material benefits to him. The victim really wanted to be free from this situation, she really wanted to return to her homeland of Indonesia, because if she had an offspring from the perpetrator, it will be difficult for her to return to Indonesia. She felt depressed and deceived by all the behavior she had received so far. There were three suspected perpetrators in this case in who had respective roles as a recruiter, a recruiter and a Chinese citizen, and the last one as an intermediary from Indonesia to China. ${ }^{7}$

The domination of women as victims of human trafficking cannot be separated from the patriarchal culture placing women in a subordinate position compared to men. Women are made into sexual objects and objects of economic exploitation. Women are seen as commodities that can be traded, even by their own families. The phenomenon of a gender perspective in human trafficking is recognized by the international community. As the implementing provisions of the United Nations Convention against Transnational Organized Crime, UN member countries agreed to form a Protocol to Prevent, Suppress and Punish Trafficking in Persons, Especially Women and Children, supplementing the United Nations Convention against Transnational Organized Crime. This international agreement was ratified by the Government of Indonesia through Law of the Republic of Indonesia Number 14 of 2009 concerning Ratification of Protocol To Prevent, Suppress And Punish Trafficking In Persons, Especially Women And Children, Supplementing The United Nations Convention Against Transnational Organized Crime (Protokol Untuk Mencegah, Menindak, dan Menghukum Perdagangan Orang, Terutama Perempuan Dan Anak-Anak, Melengkapi Konvensi Perserikatan Bangsa-Bangsa Menentang Tindak Pidana Transnasional Yang Terorganisasi). This provision regulates the protection of victims.

This study will critically discuss the phenomenon of trafficking in persons from a gender perspective, which in concrete cases of trafficking in persons, the victims are dominated by women. The perpetrators are dominated by family members who have power relations in the family, namely husbands, older brothers and fathers. This condition has actually been responded to in national and international legal policies as described above, but the root of the problem lies in the legal culture of Indonesian society which is dominated by patriarchal culture. Therefore, this research will discuss in depth the profile of victims, gender analysis, and international policies in the protection of victims that are gender equality oriented.

${ }^{7}$ Putri, A. R. H., \& Arifin, R. (2019). Perlindungan Hukum Bagi Korban Tindak Pidana Perdagangan Orang di Indonesia (Legal Protection for Victims of Human Trafficking Crimes in Indonesia). Res Judicata, 2(1), 170-185. DOI: http://dx.doi.org/10.29406/ri.v2i1.1340 


\section{ANALYSIS AND DISCUSSION}

\section{A. Profile of victims of human trafficking}

The formulation of provisions regarding the protection of trafficking in persons at the global level, one of which is regulated in the Protocol to Prevent, Suppress and Punish Trafficking in Persons, Especially Women and Children, supplementing the United Nations Convention against Transnational Organized Crime regulates the scope of the crime of trafficking in persons as regulated in Article 3a regarding Use of terms For the purposes of this Protocol, which is as follows:

Trafficking in persons" shall mean the recruitment, transportation, transfer, harbouring or receipt of persons, by means of the threat or use of force or other forms of coercion, of abduction, of fraud, of deception, of the abuse of power or of a position of vulnerability or of the giving or receiving of payments or benefits to achieve the consent of a person having control over another person, for the purpose of exploitation. Exploitation shall include, at a minimum, the exploitation of the prostitution of others or other forms of sexual exploitation, forced labour or services, slavery or practices similar to slavery, servitude or the removal of organs;

Trafficking in persons has spread in the form of organized and unorganized criminal networks, both interstate and domestic, so that it becomes a threat to society, nation and state, as well as to the norms of life based on respect for human rights. The desire to prevent and tackle the criminal act of trafficking in persons is based on noble values, national and international commitments to take preventive measures from an early age, to prosecute perpetrators, protect victims, and increase cooperation. These conditions become the basis for considering the criminal law policy against the prevention of the criminal act of trafficking in persons as regulated in the Law of the Republic of Indonesia Number 21 of 2007 concerning the Eradication of the Crime of Trafficking in Persons. In Article 1 number 1 of Law of the Republic of Indonesia Number 21 of 2007 states the definition of the crime of trafficking in persons as follows:

Trafficking in Persons is the act of recruiting, transporting, holding, sending, transferring, or accepting someone with threats of violence, use of force, kidnapping, confinement, forgery, fraud, abuse of power or vulnerable position, bondage or giving payment or benefits, so as to obtain approval from people who hold control over other people, whether done within the country or between countries, for the purpose of exploitation or causing people to be exploited.

There are three main elements contained in the meaning of trafficking. First, the element of action which includes recruiting, transporting, moving, hiding, or receiving. Second, the elements of means (means) to control victims which include threats, use of force, various forms of violence, kidnapping, fraud, cheating, abuse of power or vulnerable positions or giving or receiving or profits to obtain the consent of the person who controls 
the victim. Third, elements of the goal which include exploitation, at least for prostitution or other forms of sexual exploitation; forced labor; slavery; servitude; and organ harvesting. ${ }^{8}$

The most vulnerable to be targeted as victims by trafficking criminals are women from poor families, rural women, women dropping out of school, women looking for work, street girls or kidnapped children. Even so, it does not rule out the possibility that the victims of human trafficking are men. ${ }^{9}$ Ever since UNODC started collecting statistics on human trafficking 15 years ago, women and girls have consistently represented the majority of reported victims. The percentage of female perpetrators of trafficking who are at the same time victims of this crime, is steadily high too, especially if compared to female offenders in other crimes. The traffickers not only earned a profit by sexually exploiting the victims, but then made them commit crimes so they could escape liability and prosecution. The report shows that traffickers deliberately used the "victim-defendants" in low-level roles, that exposed them to law enforcement authorities - meaning they were more likely to get caught. ${ }^{10}$ The majority of victims of trafficking in persons are women and children who are exploited both economically and sexually. Business activities might be linked to the crime of human trafficking, for example when the workforce consists partly of victims of trafficking or when supplementary services (e.g. transport or hospitality) sectors unknowingly provide tools and loopholes to facilitate the transportation of persons being trafficked. ${ }^{11}$

Trafficking in persons is increasing because of the big profits. In fact, according to the United Nations, trafficking in persons is the most profitable criminal enterprise and is linked to money laundering, drug trafficking, document falsification and people smuggling. According to an ILO study, the benefits of trafficked women, men and children are estimated at US $\$ 32$ billion annually. The profit taken from the trafficked forced labor is approximately US $\$ 13$ per person. In a year, the profits can reach US $\$ 32$ billion. $^{12}$

The number of victims of human trafficking and the actual number of losses cannot be measured with certainty. Amy Farrell and Jessica Reichert state that current estimates of human-trafficking prevalence depend on accessing reliable statistical data about victims of human trafficking from two main sources: (a) victims who are identified by governmental and nongovernmental bodies and captured in official records and (b) victims who are

${ }^{8}$ Basuki, U. (2017). Penegakan Hukum Atas Tindak Pidana Perdagangan Orang Perspektif Hak Asasi Manusia. Varia Justicia, 13(2), 132-146. https://doi.org/10.31603/variajusticia.v13i2.1887

${ }^{9}$ Antasari, R. R. (2018). Penanganan Tindak Pidana Perdagangan Orang dalam Perspektif Global dan Islam di Provinsi Sumatera Selatan. Kafaah: Journal of Gender Studies, 8(1), 53-70. DOI: http://dx.doi.org/10.15548/ik.v1i1.198

${ }^{10}$ Noorani (2021, January 25). Shining a light on sexually exploited women and girls forced into crime. Retrieved from https://news.un.org/en/storv/2021/01/1082532

${ }_{11}$ Uhl, A., Kučera, J., Hayrapetyan, L., Gartner, M., Leuven, K. U., \& Stockreiter, S (2020, November 29). Private Sector Engagement in the Prevention of Organized Crime. htto://www.raun.org/uploads/4/7/5/4/47544571/unodc private sector engagement in the prevention of organized crime.pdf

${ }^{12}$ Salamor, Y. B. (2019). Penanggulangan tindak pidana perdagangan orang di Maluku. Jurnal Muara IImu Sosial, Humaniora, dan Seni, 2(2), 511-517. 
identified through surveys of populations of people at risk for human-trafficking victimization who may or may not be identified in any official records. ${ }^{13}$ The number of unidentified victims is believed to still exist. People who are not educated and who are in a poverty circle are lack of understanding that they have become exploited victims.

Audra Jovani analyzed that people living below the poverty line are easily offered high-wage jobs, the desire to change one's destiny is a compelling reason to work abroad. This desire is strengthened in order to pay off debts, improve family welfare, build houses and save money as business capital in the regions. This kind of situation is exploited by labor brokers to recruit the poor by promising high wages. ${ }^{14}$ However, women who come from well-off families also have the opportunity to become victims, as promised to become professional artists and models. The perpetrators use a new mode to capture victims of trafficking in persons through offering the scholarships. The National Police Headquarters exposed the human trafficking syndicate to Abu Dhabi and Taiwan. There were thousands of people who had been sent to the two countries illegally, including a new mode with the lure of scholarships in Taiwan. The suspects offered potential victims to study with scholarships while working. The capital is an administration fee of IDR 35 million. The victims' parents who are unable to provide Rp. 35 million will be given a loan by the suspects on the condition that, after the victims study while working in Taiwan, part of their income will be used to pay off the administration money paid before. ${ }^{15}$

Women are the most vulnerable group to be victims of human trafficking, especially for sexual exploitation, domestic slavery and forced marriage. Women's vulnerability of being trafficked is due to several factors. First and foremost, there is demand of women as commercial sex workers. Many women are victims of human trafficking, because they are deceived. Initially, they are offered a job as a domestic worker, a model, a job in a restaurant or another job. In other cases, women are kidnapped and threatened with violence and then trafficked. ${ }^{16}$ Trafficking of women and children is no longer limited to national borders but takes place across borders, the pattern of trafficking has changed, not only by individuals but also by organized syndicates which often have other illegal activities such as selling addictive drugs and weapons. The purpose of trafficking is no longer limited to prostitution or working in entertainment establishments, but also as migrant workers and

${ }^{13}$ Farrell, A., \& Reichert, J. (2017). Using US Law-Enforcement Data: Promise and Limits in Measuring Human Trafficking. Journal of Human Trafficking, 3(1), 39-60. https://doi.org/10.1080/23322705.2017.1280324

14 Jovani, A. (2019). Upaya Pencegahan Praktik Perdagangan Perempuan di Nusa Tenggara Timur. Jurnal Inada: Kajian Perempuan Indonesia di Daerah Tertinggal, Terdepan, dan Terluar, 2(1), 98-110. DOI: https://doi.org/10.33541/ii.v2i1.1040

${ }^{15}$ Farouk Arnaz (2019, October 9). Sindikat Perdagangan Manusia Bermodus Beasiswa Taiwan Diciduk. beritasatu.com. Retrieved from httos://www.beritasatu.com/nasional/579050/sindikat-perdagangan-manusia-bermodusbeasiswa-taiwan-diciduk

${ }^{16}$ Syamsuddin, S. (2020). Bentuk-Bentuk Perdagangan Manusia dan Masalah Psikososial Korban. Sosio Informa, 6(1). 21. 
brides. In this case, victims must face various forms of violence, such as physical, psychological, social and economic violence. ${ }^{17}$

Kiss, Ligia, dan Cathy Zimmerman state, "Human trafficking frequently involves multiple forms of abuse, including deception, coercion, extortion, threats, and, for many, physical or sexual violence."18 The case that often occurs in Indonesia is the trafficking of women into Malaysia which is carried out by organized transnational syndicates. They do this together with various modus operandi, such as changing identity, making fake passports, and other means to achieve the goal of moving women as commodities in order to get big profits. ${ }^{19}$ Cathy Zimmerman, and Ligia Kiss state the following:

Early discussions about trafficking in persons focused almost solely on sex trafficking of women and girls and drew primarily on law enforcement responses. But human trafficking is now understood more broadly to occur in a wide array of low- or no-wage hazardous labor. In fact, the contemporary amalgam of mobility and low-wage labor fosters many opportunities for labor exploitation. Men, women, and children are trafficked for various purposes, including domestic servitude, agricultural and plantation work, commercial fishing, textiles, factory labor, construction, mining, and forced sex work as well as bride trafficking and petty crime. ${ }^{20}$

The human trafficking issues can be considered as a complex phenomenon because it involves numerous basic causes and various forms of manifestations. More importantly, the practices of human trafficking are also considered as a violation of human rights. Trafficking in human also causes long misery to the victims' psychical or physical conditions. There are many reports or papers discussed the suffering condition of the victims and their families as well as the driven factors that contribute to the human trafficking. ${ }^{21}$ The phenomenon of trafficking in persons is a social problem that disrupts the stability of people's life. The real effects that can be analyzed from victims of trafficking in persons mainly result in mental disorders due to the effects of psychological trauma. ${ }^{22}$

The shame of being a victim is often followed by a feeling of sadness and helplessness which encourages them to isolate themselves from their social environment, which in turn complicates the psychological recovery process of the victim. When it is combined with the habit of maladaptive behavior that prioritizes spending time working,

\footnotetext{
17 Putri, A. H., \& Irsan, K. (2019). Penanganan Polisi terhadap Kasus Perdagangan Perempuan dan Anak di Kalimantan dan Jawa. Krtha Bhayangkara, 13(1), 188-196. DOI: https://doi.org/10.31599/krtha.v13i1.20

${ }^{18} \mathrm{Kiss}$, L., \& Zimmerman, C. (2019). Human trafficking and labor exploitation: Toward identifying, implementing, and evaluating effective responses. PLoS Med, 16(1): e1002740. https://doi.org/10.1371/journal.pmed.1002740

${ }_{19}$ Pertiwi, H. F. (2018). Analisis Modus Operandi Sindikat Women Trafficking (Studi atas Tiga Kasus Human Trafficking dari NTT dan Jakarta ke Malaysia). Jurnal Kriminologi Indonesia, 14(1), 1-13.

20 Zimmerman, C., \& Kiss, L. (2017). Human Trafficking and Exploitation: A Global Health Concern. PLoS Med, 14(11): e1002437. https://doi.org/10.1371/iournal.pmed.1002437

${ }^{21}$ Latifah, A. \& Noveria, M. (2014). The Gender Perspective on Human Trafficking in Indonesia Perdagangan Manusia di Indonesia dalam Perspektif Gender. Jurnal Masyarakat \& Budaya, 16(3): 373-382. DOI: https://doi.org/10.14203/imb.v16i3.37

${ }^{22}$ Utami, P. N. (2019). Penanganan Kasus Tindak Pidana Perdagangan Orang Oleh Pemerintah Provinsi Nusa Tenggara Timur. Jurnal HAM Vol, 10(2), 195-216. DOI: http://dx.doi.org/10.30641/ham.2019.10.195-216
} 
victims can be trapped in a mental trap that makes it difficult for them to feel complete happiness in their life. This robot-like behavior formation is conditioned due to continuous repetition of activities and is also reinforced by a sense of helplessness and limited access to health care measures. This behavior will certainly shackle the victim's freedom of thought and action, so that a slave mentality is formed. This mental state of being a slave is synonymous with the nickname of human trafficking as modern slavery. ${ }^{23}$ Chisolm-Straker, Makini, et al. state that human trafficking is "often called modern day slavery, human trafficking is a human rights violation and a clear manifestation of injustice." ${ }^{24}$ The reasons given by the victims are generally legal actions based on the agreement. Human rights violations in the form of slavery generally take the form of deprivation of freedom from a person, committed by strong economic groups to weak economic groups. Therefore, the prevention of trafficking in persons from the perspective of human rights violations must be carried out comprehensively and integrally, which can be done through the level of criminal law policy through legislation, implementation and justice. ${ }^{25}$

\section{B. Gender analysis in trafficking}

Everyone has the right to be free from various forms of human rights violations, including violence. Violence is a practice that degrades human dignity. Women are among the vulnerable groups who tend to experience violence; therefore, they need to get protection. Trafficking in women is a complex issue that requires a variety of approaches. Even so, feminist networks have an important role in fighting for women's human rights in facing patriarchal hegemony for welfare and equality in the context of trafficking in women. ${ }^{26}$ Gender analysis in dissecting the problem of trafficking in persons is very important to find out why women are more likely to be victims of trafficking in persons.

Social position and role cannot be separated from the influence of a person's gender identity, men and women will get different roles and social positions that exist in society. We can see gender differences in two different perspectives, namely a biological perspective (sex) and a social perspective (gender) in which there are significant differences between a biological and social perspective. From a biological perspective, the sexes of men and women are natural, cannot be changed and are valid forever, but if it is viewed from a social perspective, gender is constructed by the socio-cultural structure of

${ }^{23}$ Kiling, I. Y., \& Kiling-Bunga, B. N. (2019). Motif, dampak psikologis, dan dukungan pada korban perdagangan manusia di Nusa Tenggara Timur. Jurnal Psikologi Ulayat: Indonesian Journal of Indigenous Psychology, 6(1), 83-101. DOI: https://doi.org/10.24854/ipu88

${ }^{24}$ Chisolm-Straker, M., Sze, J., Einbond, J., White, J., \& Stoklosa, H. (2019). Screening for human trafficking among homeless young adults. Children and Youth Services Review, 98, 72-79. DOI: https://doi.org/10.1016/i.childvouth.2018.12.014

${ }^{25}$ Daud, B. S., \& Sopoyono, E. (2019). Penerapan Sanksi Pidana Terhadap Pelaku Perdagangan Manusia (Human Trafficking) di Indonesia. Jurnal Pembangunan Hukum Indonesia, 1(3), 352-365. DOI: https://doi.org/10.14710/iphi.v1i3.352-365

${ }^{26}$ Daud, B. S., \& Sopoyono, E. (2019). Ibid. 
society, so that it can be exchanged according to each culture which means gender construction is a social agreement. ${ }^{27}$

Patriarchal discourse is violence because it traps women by determining how they see, feel, think and act. Society has adopted patriarchal norms in every aspect of society and has become a way of life. Therefore, a constructed patriarchal system becomes a natural and common thing. Patriarchy means "father's power", in which women are in the domination of men. ${ }^{28}$ According to feminist theory, the majority of legal orders are built on a biased world view in which laws are constructed in male logic. Women are constructed to be in a lower position than men. This view has received resistance from the legal feminism theory adherents. The resistance was shown by Gramsci, namely the increase in ideological awareness. The use of this route is important, because women are already imprisoned in the ideology of male primacy. They are in a false consciousness about the reality of the world (which favor men), as if reality is normal, natural and unchangeable. As long as women are still trapped in false awareness and do not have awareness of the world they are in, then gender marginalization and discrimination will continue to be maintained. ${ }^{29}$

In a patriarchal society, there is still gender discrimination. As if women and girls are only the complement of sexuality and looked down. A culture that has taken root since long ago is very difficult to change. This condition is exacerbated by poverty, unemployment, early marriage, and the culture of people who only look for jobs, not create them. In this condition of being squeezed economically and socially, it is easy to be lured and persuaded by the brokers. They are encouraged to work in cities or abroad with the promise of high wages. ${ }^{3031}$ Wives and daughters are given to brokers to find work that will support the family's economic life, while husbands and sons stay at home without a job. Women are seen as a tradable commodity because women can provide sexual services for a fee. Women can also work, even though they do not have sufficient education. As a result, many women are sent as illegal workers abroad as domestic helpers.

The protection of women from trafficking will go hand in hand with demands for gender equality. Feminism theory assumes that there is basically no difference between men and women. Therefore, women must have the same rights as men. However, liberal

${ }^{27}$ Mutiah, R. (2019). Sistem Patriarki dan Kekerasan Atas Perempuan. KOMUNITAS, 10(1), 58-74. p, 60. DOI: https://doi.org/10.20414/komunitas.v10i1.1191

${ }^{28}$ Novarisa, G. (2019). Dominasi Patriarki Berbentuk Kekerasan Simbolik Terhadap Perempuan Pada Sinetron. Bricolage: Jurnal Magister IImu Komunikasi, 5(02), 195-211. DOI: $\frac{\text { http://dx.doi.org/10.30813/bricolage.v5i02.1888 }}{29}$ Tanya, B.L., Simanjuntak, Y.N. \& Hage, M.Y. (2010). Teori Hukum Strategi Tertib Manusia Lintas Ruang dan Generasi. Yogyakarta: Genta Publishin, pp. 182-183.

30 Hanifah, A. (2017). Perdagangan Perempuan dan Anak: Kajian Faktor Penyebab dan Alternatif Pencegahannya. Sosio Konsepsia, 13(2), 46-60.

${ }^{31}$ Wahyudin, M. A. (2018). Embodiments of the Sovereignty of the Republic of Indonesia under the Immigration Control. Substantive Justice International Journal of Law, 1(1), 9-22. DOI:

http://dx.doi.org/10.33096/substantiveiustice.v1i1.11 
feminists reject overall equality between men and women. In several respects, there is still a distinction between men and women. However, the function of the reproductive organs for women has logical consequences in social life. ${ }^{32}$

The demand for gender equality is a reality that must be faced in almost all aspects of community life. This is because the position of women in the past was considered marginalized, not seen as equal as men, and even did not have the right to make decisions. This stems from a patriarchal culture that instills an understanding that the public sphere is a male area, so that the role of women in the public sphere is generally in the subordinate position of men. Likewise, if a woman is faced with a legal process. Sometimes women find it difficult to defend themselves if the case happening to them is related to sexual violence (violence based on gender inequality). ${ }^{33}$

Sweileh stetes "Human trafficking is a crime against humanity. It is also a serious threat to global health and security. Globalization has made human trafficking an easier task for the criminal organizations." ${ }^{44}$ Female victims have not been fully protected, in fact, they often feel afraid to report due to a lack of understanding of their rights. In addition, they are also ashamed to tell others about the violence they have experienced because reporting the problem will actually become a family disgrace. These things encourage the idea that women and children victims of violence need to get protection and assistance in medical, psychological and legal matters so that problems can be resolved fairly and ensure legal certainty.

The protection of victims of the criminal act of trafficking in persons in the criminal justice system is also not optimal. In investigating court decisions that decide cases of trafficking in persons, only a few cases including the payment of restitution for victims. The judge's verdict on legal protection for victims is in the form of compensation (restitution) for the physical and psychological suffering suffered by the victim as a result of trafficking in persons. Cibadak District Court Number 396 / PID. B / 2012 / PN CBD, dated January 22, 2013 was amounting to Rp. 10,000,000, - (ten million rupiah). The decision of the Cibadak District Court Number 396 / PID.B / 2015 / PN CBD, dated January 22, 2016, regarded the case of trafficking in persons committed by the Dutch national defendant Seng Khong Ang Als Johan Bin Ang, by sexually exploiting the "virginity of his victims" in the amount of Rp. $30,000,000 \cdot 00 .{ }^{35}$

${ }^{32}$ Megawangi, R. (1999). Membiarkan Berbeda: Sudut Pandang Baru tentang Relasi Gender. Bandung: Mizan,

${ }^{33}$ Ariyanti, V. (2019). Pembaharuan Hukum Pidana di Indonesia yang Berkeadilan Gender dalam Ranah Kebijakan Formulasi, Aplikasi, dan Eksekusi. Halu Oleo Law Review, 3(2), 178-195. 182.

${ }^{34}$ Sweileh, W. M. (2018). Research Trends on Human Trafficking: A Bibliometric Analysis Using Scopus Database. Globalization and health, 14(1), 1-12. DOI: httos://doi.ora/10.1186/s12992-018-0427-9

35 Takariawan, A., \& Putri, S. A. (2018). Perlindungan Hukum Terhadap Korban Human Trafficking dalam Perspektif Hak Asasi Manusia. Jurnal Hukum lus Quia lustum, 25(2), 237-255. DOI: https://doi.org/10.20885/iustum.vol25.iss2.art2 
Providing restitution to victims will go through a long struggle through the trial process, even up to a review. The amount determined by the judge was not proportional to what was experienced by the victim. Cibadak District Court Decision No. 396/PID.B/2012/PN Cbd, dated January 22, 2013 instead stipulates a smaller compensation of Rp. 10,000,000,- compared to the amount received by the traffickers who sold them at a price of Rp. 30,000,000,-. This is certainly very ironic considering that the victims' sufferings are not only material, but also the psychological suffering they feel.

The decision of the Supreme Court Number $2401 \mathrm{~K} /$ Pid.Sus/2014 dated January 12, 2016 imposed a sentence of imprisonment for 3 (three) years and a fine of Rp60,000,000.00 (sixty million rupiah) with the provision that if the fine is not paid, then the Defendant is subject to a penalty in lieu of a fine in the form of imprisonment for 1 (one) month. This decision does not impose a criminal penalty for compensation on the victim, even though the victim other than a woman is also a child. The victim was promised a job in the form of providing massage services, but in practice, the victim was forced to provide sexual services and intercourse.

Decision Number 235/Pid.Sus/2012/PN.BGL. stated that the defendant Sri had been proven to have violated the provisions of Article 2 paragraph (1) of the Law of the Republic of Indonesia number 21 of 2007 concerning the Eradication of the Crime of Trafficking in Persons, namely "Helping to profit from the obscene acts of a woman and making it a search". The Pasuruan District Court Judge sentenced him to imprisonment for 5 (five) months and 20 (twenty) days. This decision only imposes a prison sentence and does not stipulate compensation for the victim.

\section{International policy on victim protection oriented towards gender equality}

Indonesia's constitutional reform is marked by a process of democratization in the legal sector towards a modern legal system and also external factors, namely globalization which forces the presence of foreign instruments such as international agreements in the reformed legal system as well as the supervision of every country's borders in order to maintain trade. Trade without permission is human trafficking ${ }^{36}$ Article 59 of Law Number 21 of 2007 safeguards international cooperation in effective implementation of the prevention and eradication of the criminal act of trafficking in persons. According to these provisions, the Government of the Republic of Indonesia is obliged to carry out international cooperation, whether it is bilateral, regional or multilateral. International policy in overcoming the crime of trafficking in persons is not only limited to legal issues, but also legal cultural issues that are the root of problems in trafficking in persons.

${ }^{36}$ Sitania, L. V., \& Suponyono, E. (2020). Akomodasi Pemberantasan Tindak Pidana Perdagangan Orang Dalam Aspek Hukum Internasional Dan Nasional. Jurnal Pembangunan Hukum Indonesia, 2(1), 38-54. DOI: httos://doi.org/10.14710/iphi.v2i1.38-54 
This international cooperation is a response to the profile of trafficking crimes committed by international criminal networks. Professional salespeople are usually people from organized crime syndicates that have the technology to produce passports from many countries. For developed countries, such as the United States, Germany, France, Italy, and the UK, these organized crime can change photos from illegal migrants to legal persons to enter the United States, Canada, United Kingdom, France, Italy or German. This has been happening since the 1970s. With genuine but fake passports and visas, they can fly to any country. Sometimes, these syndicates even work with embassies or consulates to make it easier to get passports or visas. ${ }^{37}$ This crime is committed in a professional and very neat manner. It causes the crime of trafficking in persons difficult to solve. Besides, it happens continuously.

In the framework of human rights protection, in essence, the protection of women is a manifestation of the right to life, the right to be free from servitude or slavery. This human right is immutable and universal, meaning that it applies to everyone regardless of origin, gender, religion and age; therefore, every country is obliged to uphold it without exception. ${ }^{38}$ Protection of human rights is carried out through legal mechanisms that are gender-just. According to Barlett, feminists who deal with law at least focus on three factors. The factors include: 1) Asking women. That is what one needs to be asked is often the silence, an isolated voice. According to Barlett, this causes by looking at the legal surface to identify the implications of gender regulations and assumptions that do not perpetuate women's subordination; 2) This method features a feminist practical understanding which can include all deductive logic, but takes into account the logic of concrete and unique experiences; 3) The emergence of awareness. The goal is for individual and collective empowerment, not for personal grudges. ${ }^{39}$

Indonesia, as a member state of the United Nations, has also signed an international legal instrument that specifically regulates efforts to prevent and eradicate transnational crimes, namely the United Nations Convention Against Transnational Organized Crime on December 15, 2000. The signing of the convention took place in Palermo, Italy. In the international convention, two protocols are stipulated in efforts to prevent and eradicate transnational crimes, namely:

Protocol to Prevent, Suppress and Punish Trafficking in Persons, Especially Women and Children, is a protocol in efforts to prevent, prosecute and punish traffickers, especially for children and women who are victims. The protocol contains measures of

\footnotetext{
${ }^{37}$ Nizmi, Y. E. (2020). Analisis Pengaruh Perang, Kemiskinan dan Diskriminasi Terhadap Perempuan dan Anak dalam Konteks Perdagangan Manusia. Review of International Relations, 2(1), $77 . \quad$ DOI: https://doi.org/10.24252/rir.v2i1.15423

${ }^{38}$ Sumirat, I. R. (2017). Perlindungan Hukum terhadap Perempuan dan Anak Korban Kejahatan Perdagangan Manusia. Jurnal Studi Gender dan Anak, 3(01), 19-30.

39 Salman, O \& Susanto, A.F. (2009). Teori Hukum Mengingat, Mengumpulkan dan Membuka Kembali. Bandung: Refika Aditama, p. 135.
} 
protection and general support for victims in the form of social support such as counselling, housing, education, medical and psychological and opportunities for victims to obtain legal status.

Protocol Against The Smuggling of Migrants By Land, sea and Air, Supplementing The United Nations Convention Against Transnational Organized Crime, a transnational effort against the criminal act of smuggling irregular migrants by land, sea or air, which was formed to complement the UN convention against organized transnational crime.

Indonesia's participation in the signing of the convention is a manifestation of the commitment of the Indonesian people in preventing and eradicating all forms of criminal acts related to human trafficking and the smuggling of illegal migrants to foreign countries, which are carried out across countries and in an organized manner by perpetrators. Indonesia has ratified international treaties that provide protection for victims of trafficking in women. This policy is legitimized through Law of the Republic of Indonesia Number 14 of 2009 concerning Ratification of Protocol to Prevent, Suppress And Punish Trafficking In Persons, Especially Women And Children, Supplementing The United Nations Convention Against Transnational Organized Crime. In the General Elucidation of Law of the Republic of Indonesia Number 14 of 2009 , it is stated as follows:

Indonesia, as the largest archipelagic country in the world, and one of the most populous countries in the world, is highly vulnerable to various forms of trafficking in persons. Trafficking in persons is a modern form of human slavery and is one of the worst forms of treatment for violations of human dignity. Based on empirical evidence, women and children are the dominant victims of the criminal act of human trafficking.

Policies at the level of legal formulation are very necessary to protect victims of human trafficking, victims of human trafficking can be identified from their distinctive characteristics, namely where victims experience physical and psychological suffering as a result of the acts of violence they receive continuously. Violence received by victims of human trafficking can be in the form of physical violence, psychological violence, sexual violence including economic violence by exploiting victims to gain economic benefits for the perpetrators. The legal construction that is expected as a form of embodiment of legal protection for victims of the crime of human trafficking in the Indonesian criminal justice system is how to form a comprehensive, integral relationship in the sense that hierarchies between systems can be built into a unified whole and comprehensive. ${ }^{40}$ Policies at the level of legal formulation are needed to protect victims of trafficking in persons. Protocol to Prevent, Suppress And Punish Trafficking In Persons, Especially Women And Children, Supplementing The United Nations Convention Against Transnational Organized Crime regulates the protection of victims, namely as follows:

${ }^{40}$ Wancik, W. (2020). Perlindungan Hukum terhadap Korban Tindak Pidana Perdagangan Orang Dalam Perspektif Sistem Peradilan Pidana Indonesia dan Malaysia. Wajah Hukum, 4(2), 261-275. DOI: http://dx.doi.org/10.33087/wih.v4i2.246 
II. Protection of victims of trafficking in persons

Article 6

Assistance to and protection of victims of trafficking in persons

1. In appropriate cases and to the extent possible under its domestic law, each State Party shall protect the privacy and identity of victims of trafficking in persons, including, inter alia, by making legal proceedings relating to such trafficking confidential.

2. Each State Party shall ensure that its domestic legal or administrative system contains measures that provide to victims of trafficking in persons, in appropriate cases:

(a) Information on relevant court and administrative proceedings;

(b) Assistance to enable their views and concerns to be presented and considered at appropriate stages of criminal proceedings against offenders, in a manner not prejudicial to the rights of the defence.

3. Each State Party shall consider implementing measures to provide for the physical, psychological and social recovery of victims of trafficking in persons, including, in appropriate cases, in cooperation with nongovernmental organizations, other relevant organizations and other elements of civil society, and, in particular, the provision of:

(a) Appropriate housing;

(b) Counselling and information, in particular as regards their legal rights, in a language that the victims of trafficking in persons can understand;

(c) Medical, psychological and material assistance; and

(d) Employment, educational and training opportunities.

4. Each State Party shall take into account, in applying the provisions of this article, the age, gender and special needs of victims of trafficking in persons, in particular the special needs of children, including appropriate housing, education and care.

5. Each State Party shall endeavour to provide for the physical safety of victims of trafficking in persons while they are within its territory.

6. Each State Party shall ensure that its domestic legal system contains measures that offer victims of trafficking in persons the possibility of obtaining compensation for damage suffered.

State Parties shall consider adopting legislative measures or other appropriate measures to permit victims of trafficking in persons to remain on its territory, temporarily or permanently, in appropriate cases. Each State Party shall give due consideration to humanitarian and compassionate factors. Protection of victims can include forms of protection that are abstract (indirect) or concrete (direct). Protection that is abstract in nature, is a form of protection that can only be felt emotionally, such as the feeling of satisfaction that comes after what the victim wants is obtained, while concrete protection is basically a form of protection that can be enjoyed in real terms, such as giving in material and non-material form. Giving the material form can be in the form of compensation or restitution, exemption from living expenses or education. Providing protection that is nonmaterial in nature can be in the form of freedom from threats, from news that undermines human dignity. ${ }^{41}$

${ }^{41}$ itasari, S. D., Sukananda, S., \& Wijaya, S. (2020). Pelaksanaan Pemberian Restitusi Terhadap Korban Tindak Pidana Perdagangan Orang. DIVERSI: Jurnal Hukum, 6(1), 92-117. DOI: https://doi.ora/10.32503/diversi.v6i1.998 
According to Article 8 of the Protocol to Prevent, Suppress And Punish Trafficking In Persons, Especially Women And Children, Supplementing The United Nations Convention Against Transnational Organized Crime, States Parties where the victim of trafficking is a citizen or where the victim has the right of permanent residence, when entering the territory of the receiving States Parties, they shall facilitate and accept it, taking into account the safety of the person, the return of the person without undue or unreasonable delay. In practice, this condition is difficult to apply. There are still many bureaucratic mechanisms that need to be passed when dealing with immigration. A diplomatic approach is indispensable in accelerating the return of victims.

International policies regarding the prevention of trafficking in persons are very good at the normative level, but it should be realized that this legal instrument focuses more on protection when a crime has been committed. Non-penal policies in changing patriarchal culture have not been widely discussed at the international level and in national legal instruments, although in the spirit of these regulations the perspective of protection for victims, namely women victims, has been seen.

\section{CONCLUSION}

The profile of victims of trafficking in persons is dominated by women who come from low-income economies. Recruitment is carried out by a criminal network that involves the people closest to the victim, namely the family and the head of the village. Women are employed at low wages and are even employed as commercial sex workers. The domination of women as victims cannot be separated from the deep rooted patriarchal culture in people's life. Men are placed in a higher position than women. Men make decisions in the family, while women are placed as executors of decisions. Women are seen as objects that can make a living for the family. Trafficking in persons is carried out across national borders, therefore, it is necessary to have an international policy in the protection of victims that is oriented towards gender equality. UN member countries made an agreement as outlined in the Protocol to Prevent, Suppress And Punish Trafficking In Persons, Especially Women And Children, Supplementing The United Nations Convention Against Transnational Organized Crime which was ratified by Law of the Republic of Indonesia Number 14 of 2009 concerning Ratification of the Protocol to Prevent, Suppress And Punish Trafficking In Persons, Especially Women And Children, Supplementing The United Nations Convention Against Transnational Organized Crime. The member states have a legal obligation to protect victims, both in the stages of prevention and treatment of victims. 


\section{REFERENCE}

Antasari, R. R. (2018). Penanganan Tindak Pidana Perdagangan Orang dalam Perspektif Global dan Islam di Provinsi Sumatera Selatan. Kafaah: Journal of Gender Studies, 8(1), 53-70. DOI: http://dx.doi.org/10.15548/jk.v1i1.198

Ariyanti, V. (2019). Pembaharuan Hukum Pidana di Indonesia yang Berkeadilan Gender dalam Ranah Kebijakan Formulasi, Aplikasi, dan Eksekusi. Halu Oleo Law Review, 3(2), 178-195. 182.

Basuki, U. (2017). Penegakan Hukum Atas Tindak Pidana Perdagangan Orang Perspektif Hak Asasi Manusia. Varia Justicia, 13(2), 132-146. https://doi.org/10.31603/variajusticia.v13i2.1887

Chisolm-Straker, M., Sze, J., Einbond, J., White, J., \& Stoklosa, H. (2019). Screening for human trafficking among homeless young adults. Children and Youth Services Review, 98, 72-79. DOI: https://doi.org/10.1016/j.childyouth.2018.12.014

Daud, B. S., \& Sopoyono, E. (2019). Penerapan Sanksi Pidana Terhadap Pelaku Perdagangan Manusia (Human Trafficking) di Indonesia. Jurnal Pembangunan Hukum Indonesia, 1(3), 352-365. DOI: https://doi.org/10.14710/iphi.v113.352-365

Farouk Arnaz (2019, October 9). Sindikat Perdagangan Manusia Bermodus Beasiswa Taiwan Diciduk. beritasatu.com. https://www.beritasatu.com/nasional/579050/sindikatperdagangan-manusia-bermodus-beasiswa-taiwan-diciduk

Farrell, A., \& Reichert, J. (2017). Using US Law-Enforcement Data: Promise and Limits in Measuring Human Trafficking. Journal of Human Trafficking, 3(1), 39-60. https://doi.org/10.1080/23322705.2017.1280324

Hanifah, A. (2017). Perdagangan Perempuan dan Anak: Kajian Faktor Penyebab dan Alternatif Pencegahannya. Sosio Konsepsia, 13(2), 46-60.

International Organization fo Migration (2019). Petunjuk Teknis Pendataan dan Pelaporan Data Tindak Pidana Perdagangan Orang. Jakarta: International Organization for Migration (IOM) Indonesia, p. 15. https://indonesia.iom.int/id/node/631

Itasari, S. D., Sukananda, S., \& Wijaya, S. (2020). Pelaksanaan Pemberian Restitusi Terhadap Korban Tindak Pidana Perdagangan Orang. DIVERSI: Jurnal Hukum, 6(1), 92-117. DOI: https://doi.org/10.32503/diversi.v6i1.998

Jovani, A. (2019). Upaya Pencegahan Praktik Perdagangan Perempuan di Nusa Tenggara Timur. Jurnal Inada: Kajian Perempuan Indonesia di Daerah Tertinggal, Terdepan, dan Terluar, 2(1), 98-110. DOI: https://doi.org/10.33541/ii.v2i1.1040

Kiling, I. Y., \& Kiling-Bunga, B. N. (2019). Motif, dampak psikologis, dan dukungan pada korban perdagangan manusia di Nusa Tenggara Timur. Jurnal Psikologi Ulayat: Indonesian Journal of Indigenous Psychology, 6(1), 83-101. DOI: https://doi.org/10.24854/jpu88 
Kiss, L., \& Zimmerman, C. (2019). Human trafficking and labor exploitation: Toward identifying, implementing, and evaluating effective responses. PLOS Med, 16(1): e1002740. https://doi.org/10.1371/journal.pmed.1002740

Krutevych, M. (2018). Separate Aspects of Criminal Responsibility for Trafficking in Human Beings. elar.naiau.kiev.ua http://elar.naiau.kiev.ua/bitstream/123456789/6411/1/111\%D0\%97\%D0\%B1\%D1\%96 \%D1\%80\%D0\%BD\%D0\%B8\%D0\%BA $2018 \% 20 \% \mathrm{D} \%$ 90\%D0\%BD\%D0\%B3\%D0 \%BB p067-069.pdf

Latifah, A. \& Noveria, M. (2014). The Gender Perspective on Human Trafficking in Indonesia Perdagangan Manusia di Indonesia dalam Perspektif Gender. Jurnal Masyarakat \& Budaya, 16(3): 373-382. DOI: https://doi.org/10.14203/imb.v16i3.37

Megawangi, R. (1999). Membiarkan Berbeda: Sudut Pandang Baru tentang Relasi Gender. Bandung: Mizan, p. 228

Mutiah, R. (2019). Sistem Patriarki dan Kekerasan Atas Perempuan. KOMUNITAS, 10(1), 5874. p, 60. DOI: https://doi.org/10.20414/komunitas.v10i1.1191

Nizmi, Y. E. (2020). Analisis Pengaruh Perang, Kemiskinan dan Diskriminasi Terhadap Perempuan dan Anak dalam Konteks Perdagangan Manusia. Review of International Relations, 2(1), 77. DOI: https://doi.org/10.24252/rir.v2i1.15423

Noorani (2021, January 25). Shining a light on sexually exploited women and girls forced into crime. Retrieved from https://news.un.org/en/story/2021/01/1082532

Novarisa, G. (2019). Dominasi Patriarki Berbentuk Kekerasan Simbolik Terhadap Perempuan Pada Sinetron. Bricolage: Jurnal Magister IImu Komunikasi, 5(02), 195-211. DOI: http://dx.doi.org/10.30813/bricolage.v5i02.1888

Nugroho, O. C. (2018). Tanggung Jawab Negara dalam Penanganan Tindak Pidana Perdagangan Orang. Jurnal Penelitian Hukum De Jure, 18(4), 543-560. DOI: http://dx.doi.org/10.30641/dejure.2018.V18.543-560

Pertiwi, H. F. (2018). Analisis Modus Operandi Sindikat Women Trafficking (Studi atas Tiga Kasus Human Trafficking dari NTT dan Jakarta ke Malaysia). Jurnal Kriminologi Indonesia, 14(1), 1-13.

Putri, A. H., \& Irsan, K. (2019). Penanganan Polisi terhadap Kasus Perdagangan Perempuan dan Anak di Kalimantan dan Jawa. Krtha Bhayangkara, 13(1), 188-196. DOI: https://doi.org/10.31599/krtha.v13i1.20

Putri, A. R. H., \& Arifin, R. (2019). Perlindungan Hukum Bagi Korban Tindak Pidana Perdagangan Orang di Indonesia (Legal Protection for Victims of Human Trafficking Crimes in Indonesia). Res Judicata, 2(1), 170-185. DOI: http://dx.doi.org/10.29406/ri.v2i1.1340 
Ria, W. Y. (2021). Perdagangan Perempuan Lintas Negara Sebagai Suatu Tindak Pidana Sebagaimana diatur Dalam Undang-Undang Nomor 21 Tahun 2007 Tentang Pemberantasan Tindak Pidana Perdagangan Orang dan CEDAW. Lex Crimen, 10(1), 30-38.

Salamor, Y. B. (2019). Penanggulangan tindak pidana perdagangan orang di Maluku. Jurnal Muara IImu Sosial, Humaniora, dan Seni, 2(2), 511-517.

Salman, O \& Susanto, A.F. (2009). Teori Hukum Mengingat, Mengumpulkan dan Membuka Kembali. Bandung: Refika Aditama, p. 135.

Sitania, L. V., \& Suponyono, E. (2020). Akomodasi Pemberantasan Tindak Pidana Perdagangan Orang Dalam Aspek Hukum Internasional Dan Nasional. Jurnal Pembangunan Hukum Indonesia, 2(1), 38-54. DOI: https://doi.org/10.14710/iphi.v2i1.38-54

Sumirat, I. R. (2017). Perlindungan Hukum terhadap Perempuan dan Anak Korban Kejahatan Perdagangan Manusia. Jurnal Studi Gender dan Anak, 3(01), 19-30.

Sweileh, W. M. (2018). Research Trends on Human Trafficking: A Bibliometric Analysis Using Scopus Database. Globalization and health, 14(1), 1-12. DOI: https://doi.org/10.1186/s12992-018-0427-9

Syamsuddin, S. (2020). Bentuk-Bentuk Perdagangan Manusia dan Masalah Psikososial Korban. Sosio Informa, 6(1). 21.

Takariawan, A., \& Putri, S. A. (2018). Perlindungan Hukum Terhadap Korban Human Trafficking dalam Perspektif Hak Asasi Manusia. Jurnal Hukum lus Quia lustum, 25(2), 237-255. DOI: https://doi.org/10.20885/iustum.vol25.iss2.art2

Tanya, B.L., Simanjuntak, Y.N. \& Hage, M.Y. (2010). Teori Hukum Strategi Tertib Manusia Lintas Ruang dan Generasi. Yogyakarta: Genta Publishin, pp. 182-183.

Todres, J., \& Diaz, A. (2021). COVID-19 and Human Trafficking the Amplified Impact on Vulnerable Populations. JAMA pediatrics, 175(2), 123-124. DOI: http://dx.doi.org/10.1001/iamapediatrics.2020.3610

Tumundo, E. (2018). Penyidikan Tindak Pidana Perdagangan Orang pada Tingkat Kepolisian dalam Perspektif Hak Asasi Manusia. Lex Et Societatis, 6(4), p. 84. DOI: https://doi.org/10.35796/les.v6i4.19834

Uhl, A., Kučera, J., Hayrapetyan, L., Gartner, M., Leuven, K. U., \& Stockreiter, S (2020, November 29). Private Sector Engagement in the Prevention of Organized Crime. http://www.ra-

un.org/uploads/4/7/5/4/47544571/unodc private sector engagement in the preventi on of organized crime.pdf 
Utami, P. N. (2019). Penanganan Kasus Tindak Pidana Perdagangan Orang Oleh Pemerintah Provinsi Nusa Tenggara Timur. Jurnal HAM Vol, 10(2), 195-216. DOI: http://dx.doi.org/10.30641/ham.2019.10.195-216

Wahyudin, M. A. (2018). Embodiments of the Sovereignty of the Republic of Indonesia under the Immigration Control. Substantive Justice International Journal of Law, 1(1), 9-22. DOI: http://dx.doi.org/10.33096/substantivejustice.v1i1.11

Wancik, W. (2020). Perlindungan Hukum terhadap Korban Tindak Pidana Perdagangan Orang Dalam Perspektif Sistem Peradilan Pidana Indonesia dan Malaysia. Wajah Hukum, 4(2), 261-275. DOI: http://dx.doi.org/10.33087/wih.v4i2.246

Zimmerman, C., \& Kiss, L. (2017). Human Trafficking and Exploitation: A Global Health Concern. PLoS Med, 14(11): e1002437. https://doi.org/10.1371/journal.pmed.1002437 